\title{
Fishes from the rio da Dona, a threatened environment in the Recôncavo Sul basin, Bahia, Brazil
}

\author{
George Vita"; Marco Tulio Oliveira Ferreiraa ${ }^{2,3}$; Washington Tavechio ${ }^{2,4}$ \& Gislaine Guidelli ${ }^{2,5}$ \\ 1 Universidade Federal da Bahia (UFBA), Instituto de Biologia (IBI0), Laboratório de Ictiologia. Salvador, BA, Brasil. \\ ORCID: http://orcid.org/0000-0003-2527-1950. E-mail: geo.vita@hotmail.com \\ 2 Universidade Federal do Recôncavo da Bahia (UFRB), Centro de Ciências Agrárias, Ambientais e Biológicas (CCAAB), \\ Laboratório de Estudos da Ictiofauna. Cruz das Almas, BA, Brasil. \\ ${ }^{3}$ ORCID: http://orcid.org/0000-0001-8496-5560. E-mail: marco_tulio_0@hotmail.com \\ ${ }^{4}$ ORCID: http://orcid.org/0000-0003-3311-1957. E-mail: tavechio@ufrb.edu.br \\ ${ }^{5}$ ORCID: http://orcid.org/0000-0003-2836-006X. E-mail: gguidelli@ufrb.edu.br
}

\begin{abstract}
The rio da Dona is an important water body in the Recôncavo Sul basin used as a water supply for the neighboring towns and for agriculture, recreation and subsistence fishing. The knowledge about the ichthyofauna of this river is scarce. In this paper, an inventory of the fish fauna from rio da Dona basin and an identification key for the species recorded are presented. Additionally, taxonomic and conservationist issues are discussed. The specimens were collected in different sites along the upper, middle and lower courses of the rio da Dona. The fishes were anesthetized, fixed in formalin, conserved in ethanol, and identified. In addition to the material collected, specimens previously deposited in the ichthyological collection of the Museu de História Natural da Bahia were also analyzed. Twenty species, distributed into 16 genera, ten families, and four orders were recorded. One of these species, Aspidoras kiriri, is endemic to the rio da Dona. Four species, Cichla pinima, Coptodon rendalli, Poecilia reticulata and Serrasalmus brandtii, have been introduced into the river. Higher richness of native species has been recorded in the upper course of the rio da Dona, while in the middle and lower parts non-native species were also representative. Along the river, a series of anthropic impacts were observed, such as deforestation of native forest including the riparian vegetation, silting and dams, which can probably compromised the resident ichthyofauna.
\end{abstract}

Key-Words. Inventory; Ichthyofauna; Impacted water body; Northeastern Mata Atlântica freshwater ecoregion.

\section{INTRODUCTION}

The Recôncavo Sul basin, state of Bahia, Brazil, is composed of a set of independent drainages, occupying a total area of $17,833 \mathrm{~km}^{2}$. It is delimited to the North by the rio Paraguaçu basin and to the South by the rio de Contas basin (Ingá, 2010). This basin is included in the "Northeastern Mata Atlântica freshwater ecoregion" proposed by Abell et al. (2008). According to Camelier \& Zanata (2014), the NMAF ecoregion is recognized because of its highly endemic ichthyofauna. The knowledge about the ichthyofauna of the Recôncavo Sul basin is scarce (Burger et al., 2011). Besides these authors, only a few studies involving the fishes from Recôncavo Sul basin have been recently conducted (Birindelli et al., 2013; Oliveira et al., 2017).

The taxonomic study conducted by Burger et al. (2011) is the broadest ichthyological survey in the Recôncavo Sul region. In their study, 16 different water bodies were sampled, including the rio da Dona, and 41 species of freshwater fishes were recorded. However, only three species were listed for the rio da Dona: Cichla pinima Kullander \& Ferreira 2006, non-native on NMAF ecoregion, Hoplias malabaricus (Bloch, 1794) and Hyphessobrycon itaparicensis Lima \& Costa 2001 (Burger et al., 2011). This small number of species listed from the rio da Dona reinforces the necessity of a broad ichthyological investigation about this still poorly known drainage.

The rio da Dona is a tributary to the the lower course of the rio Jaguaripe, another important river from Recôncavo Sul basin, supplying water to several municipalities and is used for many activities such as recreation and subsistence fishing (Gois, 2010). Besides the species listed by Burger et al. (2011) for the rio da Dona, one more species recently became known from this basin, Aspidoras kiriri Oliveira, Zanata, Tencatt \& Britto 2017. This species was described based on specimens ex- 
clusively found from rio Cai-Camarão and rio Sururu, two tributaries of the rio da Dona located in the Serra da Jibóia, an area that is now subjected to intensive agricultural activities (Poelking et al., 2015).

In this paper, a checklist of the freshwater fish species of the rio da Dona basin and an identification key are presented. Additionally, some taxonomic and conservationist issues are discussed.

\section{MATERIAL AND METHODS}

\section{Study area}

The headwaters of the rio da Dona are located on the eastern slope of the Serra da Jibóia (Oliveira et al., 2017), between the municipalities of Castro Alves and Elisio Medrado, Bahia, Brazil. This river comprises a drainage area of $776.31 \mathrm{~km}^{2}$ and its main channel covers $116.23 \mathrm{~km}$ along of the Mata Atlântica (Atlantic Forest) domain, up to the estuary formed with the rio Jaguaripe, near to the Jaguaripe municipality and Itaparica's channel (Fig. 1; Gois, 2010).

The river channel and riparian vegetation of the rio da Dona undergo abrupt changes along its course. At its upper course, the tributaries are streams, with small waterfalls and rapids, displaying a substrate composed predominantly of sand and rocks (Fig. 2A; B). The native vegetation is relatively well preserved, mainly into the Serra da Jibóia area, but a great portion of its surrounding land is occupied by farms with large pastures. The main tributaries from the upper course of the rio da Dona are rio do Melado, rio Pancada, riacho Cai-Camarão, rio Sururu, and rio da Areia.

Downstream, the rio da Dona was dammed at its middle course by EMBASA (Empresa Baiana de Águas e Saneamento), near the Santo Antônio de Jesus municipality around $23 \mathrm{~km}$ from Serra da Jibóia, to form a reservoir characterized by slow water flow, portions with high abundance of macrophytes and substrate composed of sand and clay-mud near to the margins. Native vegetation at the reservoir margins is practically absent, it was largely replaced by pastures and citrus cultivation (Fig. 2C). The reservoir covers an area of $60 \mathrm{~km}^{2}$ and holds 12.99 million $\mathrm{m}^{3}$ of water (Gois, 2010).

The rio da Dona becomes a stream with moderate water flow downstream from the dam (Fig. 2D), relatively slower than the tributaries along the Serra da Jibóia, with a substrate composed of sand and rocks until its lower course. The vegetation surrounding the river is similar to that of the reservoir area, but there is a greater portion of preserved area closer to the estuary, near the Jaguaripe municipality.

\section{Sampling and taxonomic analyses}

Six expeditions were conducted, in September, October and December 2014, June 2015, March 2017, and September 2018. The fish specimens were collected by means of hold nets, trail nets, sieves, flues, traps, and paternoster rigs. They were anesthetized in eugenol and fixed in $10 \%$ formalin solution. Subsequently, the material was transferred to $70 \%$ ethanol and deposited in the ichthyological collection of the Laboratório de Estudos da Ictiofauna of the Universidade Federal do Recôncavo da Bahia (UFRB) and the ichthyological collection of the Museu de História Natural da Bahia (UFBA). Additionally, specimens that had previously been deposited in the ichthyological collection of UFBA were also analyzed.

The fish specimens were identified to the lowest possible taxonomic level, based on identification keys and original descriptions (e.g., Burger et al., 2011; Oliveira et al., 2017), considering the relevant morphological characteristics for each group. For some particular species, specialists were also consulted. Identification key was elaborated based on analyzed specimens. The taxonomic list followed Van der Laan et al. (2019).

\section{RESULTS AND DISCUSSION}

Twenty species, distributed into 16 genera, ten families, and four orders were listed (Table 1; Fig. 3). Characiformes was the order with the highest number of species (nine), followed by Siluriformes (five), Cichliformes (four) and Cyprinodontiformes (two). The most representative family was Characidae, with six species, followed by Cichlidae (four) and Loricariidae plus Poeciliidae, with two species each.

The high number of species in Characiformes and Siluriformes was concordant with what is expected for the Neotropical ichthyofauna (Lowe-McConnell, 1999). Although Siluriformes order is dominant in South American basins (Reis et al., 2016), and, most specifically, in rivers and stream draining the Mata Atlântica domain (Menezes et al., 2007), our results were discordant with this pattern. However, the higher number of Characiformes followed by Siluriformes was concordant with the results presented by Burger et al. (2011) to the Recôncavo Sul basin. For Cyprinodontiformes, a lower diversity is observed in the Neotropical ichthyofauna (Lowe-McConnell, 1999), and also in the Recôncavo Sul basin (Burger et al., 2011), which is similar to our results.

The high number of species in Characidae (six) and Cichlidae (four) diverged somewhat from what is expected for the Neotropical ichthyofauna. The introduction of two non-native cichlids, Cichla pinima and Coptodon rendalli (Boulenger, 1897), is an important causal explanation for the current composition of the ichthyofauna from rio da Dona, with Cichlidae as the second more representative family. According to some authors (e.g., Buckup et al., 2007; Albert et al., 2011), Loricariidae is the second more representative family in Brazilian rivers. Herein, Loricariidae is represented by two species, which is similar to the number of native cichlids listed. This result also diverges from the expected to the ichthyofauna from Mata Atlântica rivers and streams, where Loricariidae is the most representative family followed by Characidae (Menezes et al., 2007). In the Recôncavo Sul 


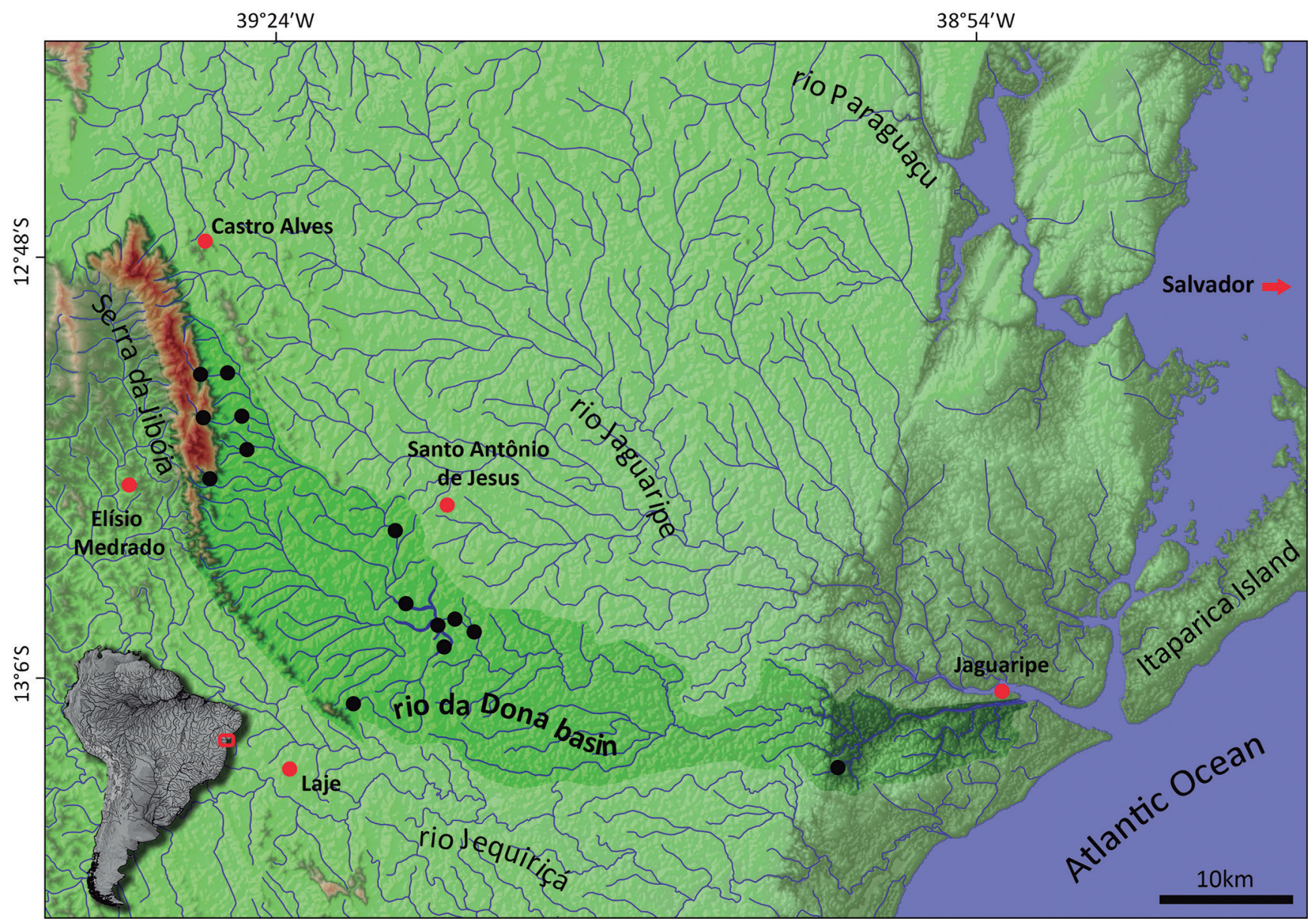

Figure 1. Partial view of the Recôncavo Sul basin, State of Bahia, highlighting the rio da Dona basin. Black points indicate localities from which specimens were analyzed, both collected and/or deposited in the Museu de História Natural da Bahia. Red points indicate the main municipalities located near the rio da Dona basin.

basin, Burger et al. (2011) also found that Characidae and Loricariidae were the most diverse lineages respectively, which thus differed from our results. The low number of loricariids is, apparently, a distinctive pattern observed in other nearby rives, such as the rio Paraguaçu and rio de Contas basins (e.g., Camelier, 2010; Camelier \& Zanata, 2014), even as to the remain rivers of the Recôncavo Sul basin (e.g., Burger et al., 2011).

Compared with the fish fauna from rio Jaguaripe sensu Burger et al. (2011), our results showed that nine of the 16 species listed by these authors for that river are present in the rio da Dona. Herein, we also found high similarity among the ichthyofauna of the rio da Dona and the North Group recovered by Camelier \& Zanata (2014), which includes the followed rivers: Paraguaçu, Pojuca, Inhambupe, Itapicuru, Real, Piaui, Vaza Barris, and Sergipe.

Among the species listed herein, three of them need taxonomic attention: Astyanax aff. fasciatus (Cuvier, 1819), Characidium aff. timbuiense Travassos 1946, and Geophagus gr. brasiliensis (Quoy \& Gaimard, 1824). The taxonomic status of Astyanax aff. fasciatus and Characidium aff. timbuiense, which are widely distributed in the Recôncavo Sul basin, was previously discussed by Burger et al. (2011). So far, no exhaustive taxonomic study involving these species has been conducted, which makes uncertain they taxonomic status. Geophagus gr. brasiliensis fits in the G. brasiliensis species group, which currently includes eight species according to Mattos \& Costa (2018), being six of them known from NMAF ecoregion. Geophagus obscurus (Castelnau 1855) and G. itapicuruensis Haseman 1911 were the first two species of the genus described from this region. Recently, four new species included in the $G$. brasiliensis complex were also described, G. diamantinensis Mattos, Costa \& Santos 2015, G. multiocellus Mattos \& Costa 2018, G. rufomarginatus Mattos \& Costa 2018 and G. santosi Mattos \& Costa 2018 . Herein, the species analyzed is tentatively identified as G. gr. brasiliensis due to the character overlap with the aforementioned species, for example, the number of branched rays of all fins. In addition, some of these species were described by Mattos \& Costa (2018) using mainly color pattern in life and molecular data, which makes it difficult to perform morphological comparisons based on the literature.

Although the rio da Dona is a relatively small drainage, the total number of species found (20) is around $49 \%$ of the total number of species listed by Burger et al. (2011) in the Recôncavo Sul basin (41). The upper course of the rio da Dona was the most species-rich stretch, with 14 species, including the endemic Aspidoras kiriri (Table 1). The occurrence of this species demonstrates the singularity of the rio Dona in the Recôncavo Sul region. After exhaustive collection effort, Aspidoras kiriri was found only in a few tributaries of the rio da Dona, in locations 
that are known to be impacted by farms according to Poelking et al. (2015). This species has been classified as Least Concern (LC, IUCN criteria) by Oliveira et al. (2017), but the potential population fragmentation and the degree of soil occupation in main tributaries of the upper course of the rio da Dona are alarming to the current the current conservation status of $A$. kiriri. In the present study, we expanded the distribution of this species to the rio Pancada (a tributary of the rio da Dona basin), at the waterfall Cachoeira do Everaldo. Thus, A. kiriri is actually known in three distant localities in the headwaters of the rio da Dona basin.

Two other species had their distribution expanded in this survey, Astyanax burgerai Zanata \& Camelier 2009 and
Parotocinclus cristatus Garavello 1977. Both species were described from rio Almada basin, southern region of the Bahia State. So far, A. burguerai have been known only from the type locality, Água Boa stream, a tributary of the rio Almada. Parotocinclus cristatus was described from a single locality in the rio Almada, however, the occurrence of this species has been previously expanded to other nearby localities. According to Camelier \& Zanata (2014), $P$. cristatus was found in four drainages from NMAF ecoregion (rio Almada, rio de Contas, rio Cachoeira, and rio Una), being rio Una and rio de Contas the southernmost and northernmost limits of distribution, respectively. Thereby, our result represents a northernmost distribution of the A. burguerai and $P$. cristatus in the NMAF ecoregion.
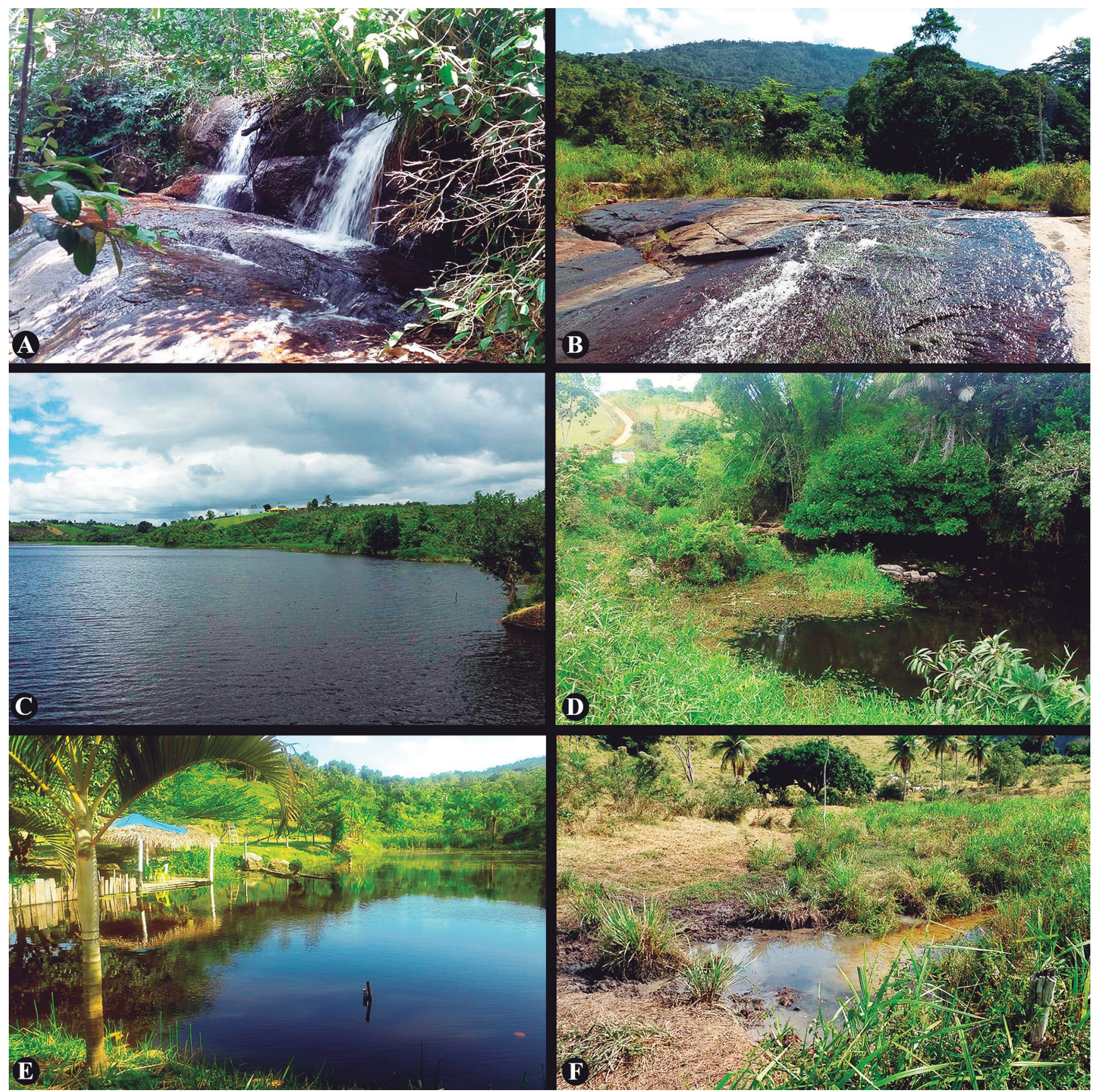

Figure 2. Some sampling sites in the rio da Dona basin. (A) rio Pancada, Serra da Jibóia, in the Mata Atlântica domain; (B) rio Pancada, at the waterfall Cachoeira do Everaldo; (C) reservoir area, with citrus-cultivation on the right margin; (D) stretch downstream from the reservoir; (E) fish-and-pay pool, in the headwaters; (F) tributary silted up through cattle movement, and surrounded by pasture. 

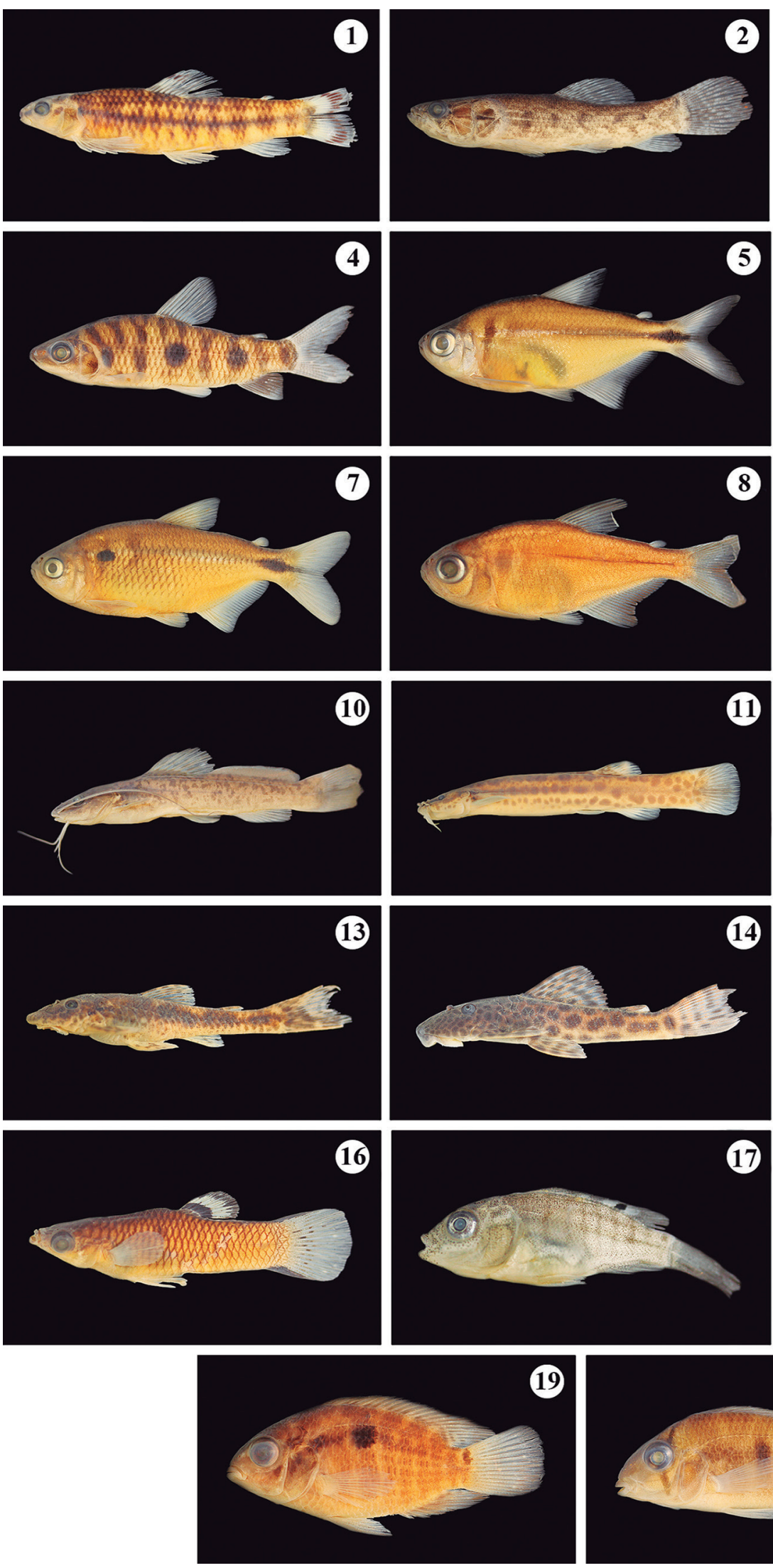

19

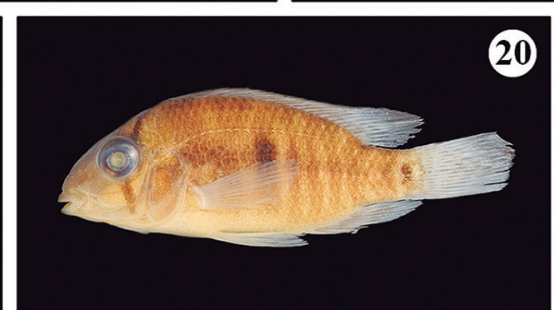

Figure 3. Representative specimens of fish species from the rio da Dona basin. The standard length of the photographed specimen follows the species name: (1) Characidium aff. timbuiense, UFBA 8325, $55.8 \mathrm{~mm}$; (2) Hoplias malabaricus, UFBA 8333, $83.6 \mathrm{~mm}$; (3) Serrasalmus brandtii, UFRB 0007, 85.0 mm; (4) Leporinus bahiensis, UFBA 8334, 58.4 mm; (5) Astyanax aff. fasciatus, UFBA 8329, $62.7 \mathrm{~mm}$; (6) Astyanax burgerai, UFBA 8369, $51.2 \mathrm{~mm}$; (7) Astyanax lacustris, UFBA 8336, $64.5 \mathrm{~mm}$; (8) Hyphessobrycon itaparicensis, UFBA 6272, $20.2 \mathrm{~mm}$; (9) Hyphessobrycon parvellus, UFRB 0019, $23.0 \mathrm{~mm}$; (10) Rhamdia quelen, UFBA 8339, $53.9 \mathrm{~mm}$; (11) Trichomycterus bahianus, UFBA 8371, $46.3 \mathrm{~mm}$; (12) Aspidoras kikiri, UFBA 8326, $36.6 \mathrm{~mm}$; (13) Parotocinclus cristatus, UFBA 8317, 36.2 mm; (14) Hypostomus unae, UFBA 8321, $61.2 \mathrm{~mm}$; (15) Poecilia reticulata, UFBA 8328, $20.5 \mathrm{~mm}$; (16) Poecilia vivipara, UFBA 6271, $31.6 \mathrm{~mm}$; (17) Coptodon rendalli, UFRB 0026, 19.0 mm; (18) Cichla pinima, UFRB 0010, 147.0 mm; (19) Cichlasoma sanctifranciscense, UFRB 0008, 47.0 mm; (20) Geophagus gr. brasiliensis, UFBA 8320, $45.1 \mathrm{~mm}$. 
Table 1. List of species recorded from rio da Dona. Species marked with $\sum$ are considered endemic and those marked with \# are considered non-native. The sampling sites are categorized as: upper course (1); middle course (2); and lower course (3).

\begin{tabular}{|c|c|}
\hline Taxonomic list & Sampling site \\
\hline \multicolumn{2}{|l|}{ Order Characiformes } \\
\hline \multicolumn{2}{|l|}{ Family Crenuchidae } \\
\hline \multicolumn{2}{|l|}{ Subfamily Characidiinae } \\
\hline Characidium aff. timbuiense Travassos 1946 & 1 \\
\hline \multicolumn{2}{|l|}{ Family Erythrinidae } \\
\hline Hoplias malabaricus (Bloch, 1794) & $1 ; 2 ; 3$ \\
\hline \multicolumn{2}{|l|}{ Family Serrasalmidae } \\
\hline Serrasalmus brandtii Lütken $1875^{\#}$ & 2 \\
\hline \multicolumn{2}{|l|}{ Family Anostomidae } \\
\hline Leporinus bahiensis Steindachner 1875 & 1 \\
\hline \multicolumn{2}{|l|}{ Family Characidae } \\
\hline \multicolumn{2}{|l|}{ Subfamily Stethaprioninae } \\
\hline Astyanax aff. fasciatus (Cuvier, 1819) & $1 ; 3$ \\
\hline Astyanax burgerai Zanata \& Canelier 2009 & 1 \\
\hline Astyanax lacustris (Lütken, 1875) & $1 ; 2$ \\
\hline Hyphessobrycon itaparicensis Lima \& Costa 2001 & 3 \\
\hline Hyphessobrycon parvellus Ellis 1911 & 2 \\
\hline
\end{tabular}

\section{Order Siluriformes}

Family Heptapteridae

Rhamdia quelen (Quoy \& Gaimard, 1824)

Family Trichomycteridae

Subfamily Trichomycterinae

Trichomycterus bahianus Costa 1992

Family Callichthyidae

Subfamily Corydoradinae

Aspidoras kiriri Oliveira, Zanata, Tencatt \& Britto 2017

Family Loricariidae

Subfamily Hypoptopomatinae

Parotocinclus cristatus Garavello 1977

Subfamily Hypostominae

Hypostomus unae (Steindachner, 1878)

Order Cyprinodontiformes

Family Poeciliidae

Subfamily Poeciliinae

Poecilia reticulata Peters $1859^{\#}$

Poecilia vivipara Bloch \& Schneider 1801

\section{Order Cichliformes}

Family Cichlidae

Subfamily Pseudocrenilabrinae

Coptodon rendalli (Boulenger, 1897)

Subfamily Cichlinae

Cichla pinima Kullander \& Ferreira 2006

Cichlasoma sanctifranciscense Kullander 1983

Geophagus gr. brasiliensis (Quoy \& Gaimard, 1824)

In the middle and lower courses of the rio da Dona, the species richness is lower than in its headwaters. On the other hand, specifically for the reservoir area, the fewer number of species may be related to the presence of non-native species. Cichla pinima, for example, is a native species from the Amazonian region, which was found in the reservoir of the rio da Dona. Although a single specimen has been collected, the reservoir is a known fishing spot of this species. Furthermore, there are also records of $C$. pinima from downstream areas. It is a predator fish usually introduced in lakes for recreational fishing, and also intentionally introduced in reservoirs for sport fishing (Agostinho \& Julio Junior, 1996). According to Burger et al. (2011), C. pinima was found only in the rio da Dona in the Recôncavo Sul basin. Furthermore, this species was also recorded in other rivers, like the Jaguaripe (personal report from fishermen) and Paraguaçu (Reis \& Santos, 2014). Reis \& Santos (2014) pointed out that native species such as Astyanax sp. and some anostomids, which are found in the rio Paraguaçu basin, are among the food items consumed by C. pinima. Impacts caused by the introduction of species of Cichla Bloch \& Schneider 1801 have been discussed by several authors (e.g., Zaret \& Paine, 1973; Gomiero \& Braga, 2004; Luiz et al., 2011).

In addition to these results, a single juvenile specimen of African tilapia (Coptodon rendalli), was collected from one tributary of the upper rio da Dona, about $10 \mathrm{~m}$ downstream from a fish-and-pay recreational lake (Fig. 2E), near the Laje municipality. At this place, the tributary was almost completely barred to form a fish-farming lake for non-native species, such as C. rendalli, Arapaima gigas (Schinz, 1822) and Cyprinus carpio Linnaeus 1758. In addition, a large specimen of $C$. rendalli (about $400 \mathrm{~mm} \mathrm{SL}$ ) was also observed being carried by a fisherman at the reservoir of the rio da Dona during one of the expeditions. In relation to the Recôncavo Sul basin, Burger et al. (2011) pointed out the presence of another tilapia species, Oreochromis niloticus (Linnaeus, 1758), which was recorded only from rio das Almas basin. As well as C. pinima, O. niloticus and other tilapias are also responsible for causing serious impacts on native fish communities (Diana et al., 1991). Poecilia reticulata Peters 1859, a native species from Venezuela, was another exotic fish recorded from the rio da Dona. This species is widely distributed in the rivers of Central and South America, introduced by aquarists and as a biological agent for mosquito control (Lucinda, 2003).

Serrasalmus brandtii Lütken (1875), native from rio São Francisco basin, was collected in the reservoir. This species was also reported from rio Jaguaripe (Burger et al., 2011) and rio de Contas as an accidental introduction (Trindade \& Jucá-Chagas, 2008). According to Oliveira et al. (2004), this species adapts easily to this type of environment and usually forms a large proportion of the local biomass. Because of the opportunist feeding habits of S. brandtii, the local aquatic fauna can be impacted by its uncontrolled presence (Pompeu, 1999). The number of fishes lacking fins or body parts that was collected in this study reinforces these arguments.

Beyond the problems directly involving the ichthyofauna of the rio da Dona, this basin is constantly impacted by and exploited for agriculture. This activity has been promoting noticeable changes, especially in the river surrounding areas (Gois, 2010). In an environmental planning study on the rio da Dona basin based on geoprocessed data, Gois (2010) showed that large areas had become degraded, with only $20,9 \%$ of the original vegetation remaining preserved. According to this author, the middle and lower courses of this river are now 
characterized by a predominance of pastures and agricultural areas, while the Serra da Jibóia and estuarine regions present better preserved vegetation, with a higher degree of native forest. This author also mentioned that losses of riparian forest had been happening from the headwaters in the direction of the main river. During the sampling expeditions, many tributaries presenting these characteristics were observed, including silting up due to the cattle movement (Fig. 2F).

According to Fischer (2007), the impacts of agriculture such as deforestation, silting and effluent discharge, including pesticide discharge, are the main factors causing degradation of the rivers in this region. Furthermore, effluent discharge and soil particles in suspension were considered by Gois (2010) to be the to be the cause of accelerating macrophytes growth in the reservoir. Most of these problems are also found in other rivers of the Recôncavo Sul basin (Burger et al., 2011). These authors remarked the rio Jaguaripe and rio Jequiriçá basins as the most impacted rivers of the Recôncavo Sul basin. This is a matter of concern, considering that the rio da Dona is located between these two basins. Therefore, it is important to emphasize the need for conservation of the rio da Dona. Some regions of its upper and lower courses, mainly into the Serra da Jibóia and near the Jaguaripe municipality respectively, need more attention due to constant risk of degradation of the river and native forest, which are still relatively preserved. In relation to the headwaters in the Serra da Jibóia, their conservation enables the protection of various important tributaries of the rio da Dona and of fish species, including the endemic and restrictedly distributed Aspidoras kiriri.

\section{ACKNOWLEDGEMENTS}

We are grateful to Beatriz Pimentel Ferreira and Vitória Lacerda (UFRB) and to Leonardo Souza Lôbo (MNRJ), for their assistance in the field; to Carolina Scherer (UFRB) for organizing the transportation for one of the expeditions, for loaning equipment for the field work and photographs; and to Angela Zanata (UFBA), for identifying some taxa, for loaning equipment for sampling and photographs.

\section{REFERENCES}

Abell, R.; Thieme, M.L.; Revenga, C.; Bryer, M.; Kottelat, M.; Bogutskaya, N.; Coad, B.; Mandrak, N.; Balderas, S.C.; Bussing, W.; Stiassny, M.L.J.;Skelton, P.; Allen, G.R.; Unmack, P.; Naseka, A.; Ng, R.; Sindorf, N.; Robertson, J.; Armijo, E.; Higgins, J.V.; Heibel, T.J.; Wikramanayake, E.; Olson, D.; López, H.L.; Reis, R.E.; Lundberg, J.G.; Pérez, M.H.S. \& Petry, P. 2008. Freshwater ecoregions of the world: A new map of biogeographic units for freshwater biodiversity conservation. Bioscience, v. 58(5): 403-414.

Agostinho, A.A. \& Julio Junior, H.F. 1996. Peixes de outras águas: ameaça ecológica. Ciência Hoje, v. 21: 36-44.

Albert, J.S.; Bart Jr., H.L. \& Reis, R.E. 2011. Species richness and cladal diversity. In: Albert, J.S. \& Reis, R.E. Historical biogeography of neotropical freshwater fishes. Berkeley, University of California Press. p. 89-104.
Birindelli, J.L.; Britski, H.A. \& Garavello, J.C. 2013. Two new species of Leporinus Agassiz (Characiformes: Anostomidae) from eastern basins of Brazil, and redescription of L. melanopleura Günther. Neotropical Ichthyology, 11: 9-23.

Buckup, P.A.; Menezes, N.A. \& Ghazzi, M.S. 2007. Catálogo das espécies de peixes de água doce do Brasil. Rio de Janeiro, Museu Nacional.

Burger, R.; Zanata, A.M. \& Camelier, P. 2011. Estudo taxonômico da ictiofauna de água doce da bacia do Recôncavo Sul, Bahia, Brasil. Biota Neotropica, 11(4): 273-290.

Camelier, P. 2010. Estudo taxonômico e aspectos biogeográficos da ictiofauna de água doce de drenagens costeiras do Estado da Bahia, Brasil, com a descrição de seis espécies novas (Masters Dissertation). Universidade Federal da Bahia, Salvador.

Camelier, P. \& Zanata, A.M. 2014. Biogeography of freshwater fishes from the Northeastern Mata Atlântica freshwater ecoregion: distribution, endemism, and area relationships. Neotropical Ichthyology, 12: 683-698.

Diana, J.S.; Dettweiler, D.J. \& Lin, C.K. 1991. Effect of Nile tilapia (Oreochromis niloticus) on the ecosystem of aquaculture ponds, and its significance to the trophic cascade hypothesis. Canadian Journal of Fisheries and Aquatic Sciences, 48(2): 183-190.

Fischer, F. 2007. Baixo Sul da Bahia: uma proposta de desenvolvimento territorial. Salvador, CIAGS/UFBA.

Gois, D.V. 2010. Planejamento ambiental e uso do geoprocessamento no ordenamento da Bacia Hidrográfica do rio da Dona. (Doctoral Thesis). Universidade Federal de Sergipe, Aracaju.

Gomiero, L.M. \& Braga, F.M.S. 2004. Feeding of introduced species of Cichla (Perciformes, Cichlidae) in Volta Grande Reservoir, river Grande (MG/SP). Brazilian Journal of Biology, 64(4): 787-795.

Instituto de Gestão das Águas e Clima (INGÁ). 2010. Programa de Monitoramento da Qualidade das Águas do Estado da Bahia. Avaliable at: http://www.inga.ba.gov.br. Access in: 22/04/2014.

Lowe-McConnell, R.H. 1999. Estudos ecológicos de comunidades de peixes tropicais. São Paulo, Edusp.

Lucinda, P.H.F. 2003. Family Poeciliidae. In: R.E. Reis; S.O. Kullander \& C.J. Ferraris-Junior. Check List of the Freshwater Fishes of South and Central America. Porto Alegre, Edipucrs. p. 555-581.

Luiz, F.T.; Velludo, M.R.; Peret, A.C.; Rodrigues Filho, J.L. \& Peret, A.M. 2011. Diet, reproduction and population structure of the introduced Amazonian fish Cichla piquiti (Perciformes: Cichlidae) in the Cachoeira Dourada reservoir (Paranaíba River, central Brazil). Revista de Biología Tropical, 59(2): 727-741.

Mattos, J.L. \& Costa, W.J. 2018. Three new species of the 'Geophagus' brasiliensis species group from the northeast Brazil (Cichlidae, Geophagini). Zoosystematics and Evolution, 94(2): 325-337.

Menezes, N.A.; Weitzman, S.H.; Oyakawa, 0.T.; de Lima, F.C.T.; Castro, R.M.C. \& Weitzman, M.J. 2007. Peixes de água doce da Mata Atlântica: lista preliminar das espécies e comentários sobre conservação de peixes de água doce neotropicais. São Paulo, Museu de Zoologia da Universidade de São Paulo.

Oliveira, A.K.; Alvim, M.C.C.; Peret, A.C. \& Alves, C.B.M. 2004. Diet shifts related to body size of the pirambeba Serrasalmus brandtii Lütken, 1875 (Osteichthyes, Serrasalminae) in the Cajuru reservoir, São Francisco river basin, Brazil. Brazilian Journal of Biology, 64(1): 117-124.

Oliveira, L.; Zanata, A.M.; Tencatt, L.F. \& Britto, M.R. 2017. A new species of Aspidoras (Siluriformes: Callichthyidae) from a small coastal drainage in northeastern Brazil. Neotropical Ichthyology, 15: 1-8.

Poelking, E.L.; Costa, 0.V. \& Gloaguen, T.V. 2015. Estudos técnicos sobre a Serra da Jiboia - Caracterização do meio físico: geologia, geomorfologia, hidrografia e pedologia. In: Blengini, I.A.D.; Cintra, M.A.M. de U. \& Cunha, R.P.P. Proposta de Unidade de Conservação da Serra da Jibóia. Salvador, Gambá (Grupo Ambientalista da Bahia). 1:35-70. 
Pompeu, P.S. 1999. Dieta da pirambeba Serrasalmus brandtii Reinhardt (Teleostei, Characidae) em quatro lagoas marginais do rio São Francisco, Brasil. Revista brasileira de Zoologia, 16: 19-26.

Reis, L.R.G. \& Santos, A.C.A. 2014. Dieta de duas espécies de peixes da família Cichlidae (Astronotus ocellatus e Cichla pinima) introduzidos no rio Paraguaçu, Bahia. Revista Biotemas, 27: 83-91.

Reis, R.E.; Albert, J.S.; Di Dario, F.; Mincarone, M.M.; Petry, P. \& Rocha, L.A. 2016. Fish biodiversity and conservation in South America. Journal of fish Biology, 89: 12-47.
Trindade, M.E.D.J. \& Jucá-Chagas, R. 2008. Diet of two serrasalmin species, Pygocentrus piraya and Serrasalmus brandtii (Teleostei: Characidae), along a stretch of the rio de Contas, Bahia, Brazil. Neotropical Ichthyology, 6(4): 645-650.

Van der Laan, R.; Fricke, R. \& Eschmeyer, W.N. 2019. Eschmeyer's catalog of fishes: Classification. Available at: http://www.calacademy.org/ scientists/catalog-of-fishes-classification. Access in: 12/09/2019.

Zaret, T.M. \& Paine, T.R.T. 1973. Species introduction in a tropical lake. Science, 182(411): 445-449. 


\section{APPENDIX 1. EXAMINED MATERIAL}

The presentation of the species follows alphabetical order, for the respective orders; ( $\mathrm{SL}=$ standard length). The vouchers followed by asterisk are paratypes. All from rio da Dona basin, Bahia state, Brazil, except UFBA 4346 (paratype of Astyanax burgerai from type locality, rio Almada basin, Bahia).

\section{Characiformes}

Astyanax aff. fasciatus: UFRB 0005, 1 (33.0 mm SL); UFRB 0020, 13 (35.0-49.0 mm SL); UFBA 6289, 4 (54.5-60.8 mm SL); UFBA 8315, 3 (21.1-42.8 mm SL); UFBA 8329, 2 (52.8-62.7 mm SL); UFBA 8332, 14 (20.5-46.4 mm SL).

Astyanax burgerai: UFBA 4346*, 15 (19.5-54.4 mm SL); UFBA 7427, 2 (43.8-64.2 mm SL); UFBA 7437, 9 (28.7-44.8 mm SL); UFBA 7351, 1 (34.5 mm SL); UFBA 7460, 5 (36.4-51.3 mm SL); UFBA 8118, 13 (17.2-46.3 mm SL); UFBA 8319, 14 (17.7-38.3 mm SL);UFBA 8323,31 (28.8-54.2 mm SL);UFBA8330,51 (14.0-38.5 mm SL);UFBA8340,20 (23.6-33.1 mm SL); UFBA 8369, 23 (32.0-74.4 mm SL); UFBA 8688, 4 (22.0-26.0 mm SL).

Astyanax lacustris: UFRB 0004, 2 (50.0-59.0 mm SL); UFRB 0006, 46 (36.0-62.0 mm SL); UFRB 0011, 1 (15.0 mm SL); UFRB 0013， 2 (19.0-20.0 mm SL); UFRB 0017， 3 (14.0-38.0 mm SL); UFRB 0022， 5 (31.0-38.0 mm SL); UFRB 0027, 8 (13.0-52.0 mm SL); UFBA 8318, 8 (20.4-32.9 mm SL); UFBA 8327, 8 (28.0-45.3 mm SL); UFBA 8335, 2 (34.9-35.8 mm SL); UFBA 8336, 3 (53.5-64.5 mm SL).

Characidium aff. timbuiense: UFBA 7428, 22 (25.9-40.0 mmSL); UFBA 7436, 23 (26.7-36.3 mm SL); UFBA 7452, 8 (26.0-36.3 mm SL); UFBA 7461, 23 (29.0-48.5 mm SL); UFBA 7880, 5 (28.1-40.0 mm SL); UFBA 8324, 5 (33.5-59.7 mm SL); UFBA 8325, 14 (31.2-55.8 mm SL); UFBA 8338, 1 (26.8 mm SL); UFBA 8370, 10 (30.5-41.1 mm SL).

Hoplias malabaricus: UFRB 0003, 1 (17.0 mm SL); UFRB 0015, 1 (21.0 mm SL); UFBA 6270, 1 (45.5 mm SL); UFBA 8322, 1 (52.4 mm SL); UFBA 8333, 2 (76.0-83.6 mm SL).

Hyphessobrycon itaparicensis: UFBA 6271, 9 (12.3-20.2 mm SL).

Hyphessobrycon parvellus: UFRB 0019, 8 (19.0-23.0 mm SL).

Leporinus bahiensis: UFBA 8334, 1 (58.4 mm SL).

Serrasalmus brandtii: UFRB 0002, 5 (18.0-32.0 mm SL); UFRB 0007, 1 (85.0 mm SL); UFRB 0009, 17 (76.0-121.0 mm SL).

\section{Siluriformes}

Aspidoras kiriri: UFBA 7111*, 2 (26.4-28.0 mm SL); UFBA 7352*, 2 (26.4-27.8 mm SL); UFBA 7426*, 3 (20,9-27,5 mm SL); UFBA 7435*, 2 (26.5-28.6 mm SL); UFBA 7453*, 1 (30.9 mm SL); UFBA 7458* 3 (23.4-30.8 mm SL); UFBA 7712*, 10 (11.1-27.7 mm SL); UFBA 7719*, 1 (35.6 mm SL); UFBA 8119*, 5 (17.0-27.4 mm SL); UFBA 8326, 14 (21.48-36.6 mm SL); UFBA 8337, 30 (20.4-34.8 mm SL); UFBA 8368, 5 (18.0-25.8 mm SL); UFBA 8481, 3 (24.8-34.4).

Hypostomus unae: UFRB 0024, 1 (44.0 mm SL); UFBA 8321, 9 (20.0-61.2 mm SL); UFBA 8331, 1 (18.1 mm SL).

Parotocincluscristatus:UFRB0025,3 (27.0-30.0 mm SL);UFBA8316,3 (23.9-27.7 mm SL);UFBA8317, 10 (23.8-36.2 mm SL). Rhamdia quelen: UFRB 0023, 2 (64.0-81.0 mm SL); UFBA 8339, 1 (53.9 mm SL).

Tichomycterus bahianus: UFBA 7459, 1 (26.8 mm SL); UFBA 8120, 2 (42.2-66.7 mm SL); UFBA 8371, 1 (46.3 mm SL).

\section{Cyprinodontiformes}

Poecilia reticulata: UFRB 0001, 53 (11.0-19.0 mm SL); UFRB 0012, 38 (12.0-23.0 mm SL); UFRB 0014, 85 (11.0-22.0 mm SL); UFRB 0016, 15 (12.0-23.0 mm SL); UFRB 0018, 28 (11.0-21.0 mm SL); UFRB 0021， 3 (22.0-28.0 mm SL); UFBA 8328, 2 (18.4-20.5 mm SL).

Poecilia vivipara: UFBA 6271, 3 (27.0-31.6 mm SL).

\section{Cichliformes}

Cichla pinima: UFRB 0010, 1 (147.0 mm SL); UFBA 6290, 1 (60.5 mm SL).

Cichlasoma sanctifranciscense: UFRB 0008, 3 (47.0-70.0 mm SL).

Coptodon rendalli: UFRB 0026, 1 (19.0 mm SL).

Geophagus gr. brasiliensis: UFBA 8320, 4 (11.1-45.1 mm SL); UFBA 8372, 4 (31.4-69.0 mm SL). 


\section{APPENDIX 2. IDENTIFICATION KEY FOR FISH SPECIES OF THE RIO DA DONA BASIN}

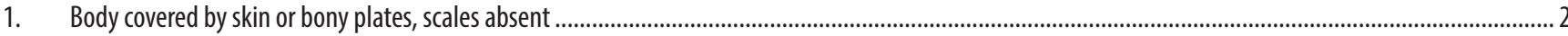

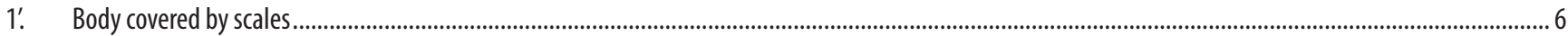

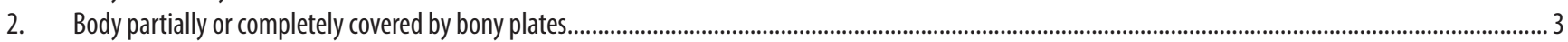

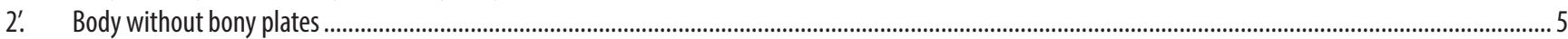

3. Two longitudinal series of bony plates on the lateral of body; mouth subterminal.................................................................................... Aspidoras kiriri

3. $\quad$ Three or more longitudinal series of bony plates on the lateral of body; mouth ventral and sucker-like ............................................................................ 4

4. Absence of tuft of denticles on the occiput; scapular bridge non-exposed and weakly covered by dispersed small plates; ventral surface weakly covered by small plates; body and fins with large dark rounded spots bigger than those on the head.......................................................................... Hypostomus unae

4. $\quad$ Tuft of denticles present; scapular bridge exposed and entirely covered by odontodes; ventral surface covered by large lateral plates and numerous small plates grouped medially; presence of a light brown strip from snout tip to caudal fin, with four dark vertical bars on the trunk and fin rays with small dark spots.

Parotocinclus cristatus

5. Presence of odontodes on the opercle; absence of pungent spine on the fins; adipose fin absent.................................................... Trichomycterus bahianus

5. $\quad$ Opercle without odontodes; presence of pungent spine on pectoral fins; adipose fin present...................................................................... Rhamdia quelen

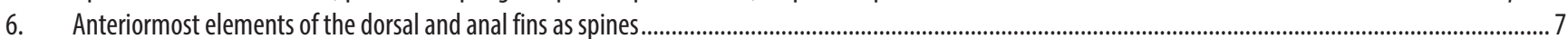

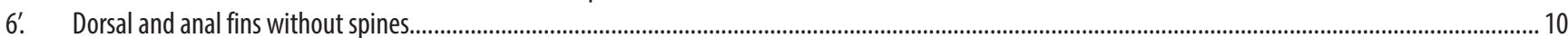

7. Upper branch of the first gill arch with lobe ......................................................................................................................... Geophagus gr. brasiliensis

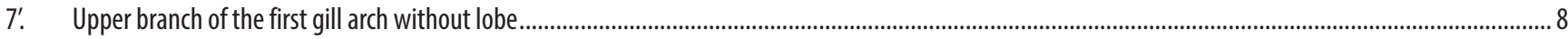

8. Four spines on the anal fin; oval dark blotch in the middle body.......................................................................................... Cichlasoma sanctifranciscense

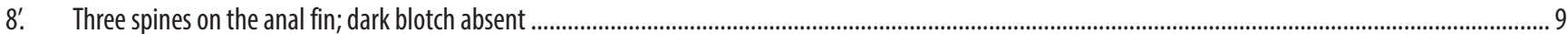

9. Spines of the dorsal fin separated from the soft-branched rays by a notch; presence of an ocellus-shaped caudal blotch...................................... iichla pinima

9. $\quad$ Dorsal fin without a notch; caudal blotch absent .......................................................................................................................................... Coptodon rendalli

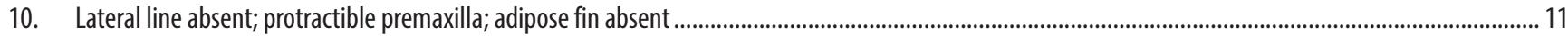

10'. Lateral line partially or completely present; non-protractible premaxilla; adipose fin usually present........................................................................... 12

11. Males and females with a single dark blotch on the lateral of the body, anteriorly to dorsal fin; males with same color pattern as females...... Poecilia vivipara

11. Females without a dark blotch on the lateral of the body; males with different color pattern than females (green, blue and/or red blotches in live specimens), and may present more than one dark blotch on the lateral of the body.

..Poecilia reticulata

12. Only conical and canine teeth present; adipose fin absent; rounded caudal fin.

Hoplias malabaricus

12'. Conical, incisive, truncated and/or multicuspid teeth; adipose fin present; caudal fin bifurcated or emarginated.

13

13. Cranium without frontal fontanelle; tiny subterminal mouth; "3"-shaped bar on caudal fin present

Characidium aff. timbuiense

13. Frontal fontanelle present; mouth large; "3"-shaped bar on caudal fin absent ... 14

14. Incisive teeth; three or four teeth on each side of the premaxilla and the dentary; gill membranes attached to the isthmus Leporinus bahiensis

14. Conical and/or multicuspid teeth; more than four teeth on the premaxilla and dentary.

15. Premaxilla with a single tooth series; sharp tricuspid teeth on both premaxilla and dentary; abdomen compressed with a keel of spines preceding pelvic fins Serrasalmus brandtii

15. $\quad$ Premaxilla with two tooth series; teeth variably shaped; abdomen non-compressed and without keel of spines ............................................................. 16

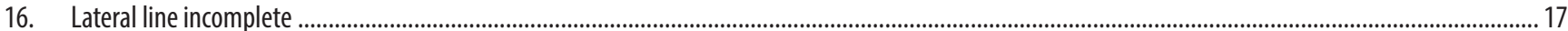

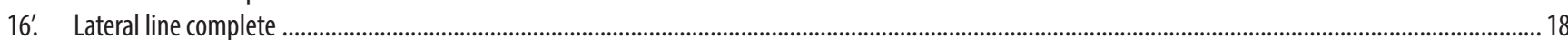

17. Pseudotympanum present; humeral blotch absent; dark conspicuous caudal-peduncle blotch usually present

17. Pseudotympanum absent; faint vertically elongate humeral blotch present; caudal-peduncle blotch absent.

18. Well-defined and horizontally elongated humeral blotch; maxillary teeth absent...... Hyphessobrycon parvellus

8'. One or two vertically elongated humeral blotches; at least one maxilla tooth present Hyphessobrycon itaparicenscis

9. One humeral blotch with straight edges; one tooth on the maxilla; $24-28$ branched rays on the anal fin ..Astyanax lacustris Astyanax aff. fasciatus

19. Two humeral blotches, being the anteriormost comma-shaped, wider dorsally; up to two maxillary teeth; $18-20$ branched rays on the anal fin

Astyanax burgerai 